\title{
EXPERIMENT ON THE MANAGEMENT OF THE LAST MINUTES IN A FOOTBALL GAME OF REPUBLICAN J UNIORS
}

\author{
Savu Vasile Cătălin ${ }^{1 *}$ \\ Moisescu Petronel Cristian² \\ 1,2 “Dunarea de Jos” University of Galați, 63-65, Garii, 800003, Romania
}

Keywords: football, end of the game, concentration, juniors

\begin{abstract}
There are a multitude of factors that may influence the efficiency of a junior football player towards the end of a match; a technical error, a deficient physical condition or a lack of concentration, which lead in most cases to the loss of the match or points. Coaches from various junior teams and even senior teams, so as to motivate the negative result, explain the failures or the lack of efficiency of a player or of the teams they run by using the sentence, "in decisive moments of the match my players have given proof of lack of concentration". In this respect, in order to find the determining factor, we have to do a thorough analysis on the management of the last minutes of a football match, so that we can identify and fight its negative effects in the future.
\end{abstract}

\section{Introduction}

As for the coach, his role lies not only in the preparation of the athletes but also in making players do the best they can during the matches, but especially during the end of the matches when both internal and external factors are involved (the stakes of the game, the public pressure, fatigue, poor performance of referees, precipitation, emotions, etc.-Mazzantini, Bombardieri, 2013). To make this happen the coach needs to know in detail the strengths and the weaknesses of every player but also those of the whole team, as a result of objective tests and analyses, in order to take the necessary decisions in important moments of the match. These tests and analyses refer to all training factors, although some specialists (Epuran, Holdevici, Toniţă, 2001 and Hniatiuc, 2008) consider that match endings relate to the psyche of the players, to their ability to raise and concentrate their attention.

So attention is necessary for any type of activity, it is involved in any conscious activity, accompanying all mental processes (Cottraux, 2005).

Referring to the football game, the maximum and lasting requests during a match gradually decrease the attention (Rădulescu, Cojocaru, 2003). For this

\footnotetext{
*E-mail: catalin_savu_1971@yahoo.com
} 
reason, if we want to find out the cause of a player's failures we must first evaluate his capacity for each factor of sport training (Dragan, Oprea, 2007).

In conclusion, for a good management of the end of the match, the coach should know very well the psychological profile of each player (qualities + defects) and that of the group (relationships, conflicts between players, ethnic, religious issues, etc.) in order to take the best decisions during the game but especially in critical and tense moments towards the end of the game.

The purpose of this paper is to identify and fight against factors which may influence the efficiency of a junior soccer player towards the end of a game, through the implementation of specific means of training, in order to obtain superior results in the competition.

Hypotheses of the research:

1. It is considered that identifying and fighting against those factors which may influence the efficiency of a junior soccer player towards the end of a game, can lead to superior results in competitions.

2. To what extent the methods and means used at the end of the training will influence the ability of management of the last minutes of the match at the level of junior republicans.

\section{Material and methods}

The groups included in the research are the following: A.S.C.M.Dunărea Galaţi - the experimental group and L.P.S. Galaţi - the control group made of juniors under 19 each group including 18 players.

The experiment was carried out on the "Danube 2" and, "Siderurgistul" pitches in Galaţi, where the playing area is made of artificial grass, so that training teams was not influenced by weather conditions.

This experiment took place during a return competition (01.03.201631.05.2016).

Assessment tests - For the analysis of the factors of sports training which may influence the management of the last minutes of a football match, a number of three tests were applied.

Description of the tests:

1. In order to measure the physical factor we applied the $2000 \mathrm{~m}$

Endurance test

Execution: On the command "ready" the players go close to the start line, without touching it. On whistling (or using an acoustic signal) they run on 2000 $\mathrm{m}$ as fast as possible. The timer is stopped the moment the runner's chest goes over the finish line.

2. In order to measure the technical factor we applied the Long Pass test

Marking: the marking of the $5 \mathrm{~m}$ square must be visibile.

Execution: the players must execute 3 long passes in the square with a 5 m side. 
Rules:

- the ball is static. The ball falls on the border line of the square = success.

- successful long pass $=20$ PTS

Result: the sum of points.

3. In order to test the psychological factor we applied the Toulouse-Pieron concentrated attention test

Content:

- 4 squares each one with a slash in a different position, used as models;

- 23 rows of 20 squares with the slash placed either in the corners or on the sides of the square.

- Subject task:

- is to find and to cross out the four square types given as a model, working simultaneously;

- if the subjects identifies an error he can correct it.

Duration: 6 minutes

Analysis of the results:

This test allows the diagnois of the attention from the quantitative and qualitative point of view. On the right side of the page we will have 3 columns:

- c-representing correctly crossed out signs

- g- representing incorrectly crossed out signs

- o-representing omitted signs.

In order to assess quality we apply the formula :Quality $=\mathrm{Tc}-\mathrm{Tg} / \mathrm{Tc}+\mathrm{To}$

After the analysis of the results of the initial tests, an experimental training program was developed and applied for the experimental group; it contained specific means aimed at developing sports training factors, in order to manage at a higher level the last minutes of a match. The experimental preparatory program was structured over the course of 3 months, with three sessions per week (Monday, Wednesday and Friday) 10 minutes before the players' recovery after exercise.

The control group worked using their own training program, which consisted of training towards the end of the training session by two gate shooting games on half of the field. Among the exercises used to upgrade the training factors, we mention the following:

1. $4 \times 4$ Games - In a 30x20m square, we have 4 teams of 2 players each wearing different t-shirts. 2 teams has two different colours play (e.g. red + green-yellow + blue). Each color has a gate with the same colur as the t-shirts, made of markers at a distance of two metres. When a team has the ball they must score in the coloured gates of the other teams. Teams are changing at the coach's whistle after some time and try to score in the new gates. Working time 2 rounds $x 4^{\prime}$; break 1 '.

2. $5 \times 5$ Games - In a 30x20m square, two gates of 5/2 m with goalkeepers. We have 4 teams of two players with different t-shirts (red, orange, green, blue). 
They play 4 against 4 but each team consists of 2 groups of players with the same t-shirts (e.g. red + blue versus orange + green). The coach announces the starting teams and during the game the teams change accoding to color and each team will attack at the indicated gate. Working 3 sessions $x 3$ '; break 1 '.

3. $5 \times 5$ Games - In $45 x 30 \mathrm{~m}$ square, 2 normal gates with 2 goalkeepers. They play in the area in the middle of the square, in pairs of players with strict marking each pair having a number. After a certain number of passes, the coach calls a number, and the player in possession of the ball must pass "to the number shouted that can enter the completion area on 1 x 1 with the goalkeeper. The pair must prevent him from completing. Workinh 2 sessions x 5 '; break 1 '.

4. $5 \times 5$ Games - A square of $40 \times 40 \mathrm{~m}$. They play at a small improvised normal gate, made of markers, placed in the middle of the field, two goalkeepers defending the gate, with the back at each other, or one goalkeeper who must go wherever the ball goes. They play with two and one touch. They score from anywhere. They can also perform a long pass over the gate and complete from the opposite direction. Working time 2 sessions $\mathrm{x} 4$ ' ; break 1 '.

5. $5 \times 5$ Games - A square of 50x20m, divided into three parts, two gates of $5 / 2 \mathrm{~m}$ with goalkeepers.

Two 20x20m areas and one $10 \times 20 \mathrm{~m}$ area. In the 20x20m area they play 2 $\mathrm{x} 2$, and in the $10 \mathrm{x} 20 \mathrm{~m}$ area they play $1 \times 1$ the player having to put forward the strikers. This player may not participate in the completion. Strikers must score through individual action or through combinations with teammates, as many goals as possible. Defenders must prevent strikers from scoring, and if they recover the ball they must play as soon as possible with a midfielder. Working time 2 sessions x 5 '; break 1 '.

\section{Results and disscusions}

After the application of the experimental training program the following result were recorded:

Tabel 1 Results obtained after the test

\begin{tabular}{|c|c|c|c|c|c|c|c|c|c|c|c|c|}
\hline \multirow{3}{*}{$\begin{array}{c}\text { Test } \\
\text { Group } \\
\text { Test } \\
\end{array}$} & \multicolumn{4}{|c|}{$\begin{array}{c}\begin{array}{c}\text { Endurance 2000 m } \\
\text { (minutes) }\end{array} \\
\end{array}$} & \multicolumn{4}{|c|}{$\begin{array}{c}\text { Long pass } \\
\text { (points) }\end{array}$} & \multicolumn{4}{|c|}{$\begin{array}{c}\text { Toulouse-Pieron } \\
\text { (qualitative model score) }\end{array}$} \\
\hline & \multicolumn{2}{|c|}{ Experiment } & \multicolumn{2}{|c|}{ Control } & \multicolumn{2}{|c|}{\begin{tabular}{|l|} 
Experiment \\
\end{tabular}} & \multicolumn{2}{|c|}{ Control } & \multicolumn{2}{|c|}{ Experiment } & \multicolumn{2}{|c|}{ Control } \\
\hline & Initial & Final & Initial & Final & Initial & Final & Initial & Final & Initial & Final & Initial & Final \\
\hline Arithmetic mean & 7.54 & 7.35 & 7.50 & 7.36 & 32.30 & 38.46 & 33.84 & 36.92 & 25 & 60.55 & 27.5 & 34.16 \\
\hline $\begin{array}{l}\text { Standard } \\
\text { deviation }\end{array}$ & 0.171 & 0.049 & 0.185 & 0.065 & $\mid 10.12$ & 9.87 & 9.60 & 11.09 & 4.20 & 6.39 & 6.47 & 8.08 \\
\hline Coef. Of variation. $\%$ & 2.278 & 0.66 & 2.471 & 0.88 & 31.34 & 25.66 & 28.38 & 30.04 & 16.80 & 10.55 & 23.54 & 23.67 \\
\hline Average error m & 0.04 & 0.0115 & $\mid 0.043$ & $\mid 0.015$ & 2.38 & 2.32 & 2.26 & 2.61 & 0.99 & 1.50 & 1.52 & 1.907 \\
\hline $\mathbf{m}^{2}$ & 0.0016 & 0.00013 & 0.0019 & 0.0002 & 5.7 & 5.41 & 5.13 & \begin{tabular}{|l|l|}
6.84 \\
\end{tabular} & 0.98 & \begin{tabular}{|l|}
2.27 \\
\end{tabular} & 2.33 & 3.64 \\
\hline $\begin{array}{c}\text { Signif. test. } \\
\mathbf{t}=1.95\end{array}$ & & 0.017 & & & & & 1.5 & & & & 10.86 & \\
\hline
\end{tabular}


Graphical expression regarding the arithmetic mean of the initial and final tests „Endurance 2000 meters”

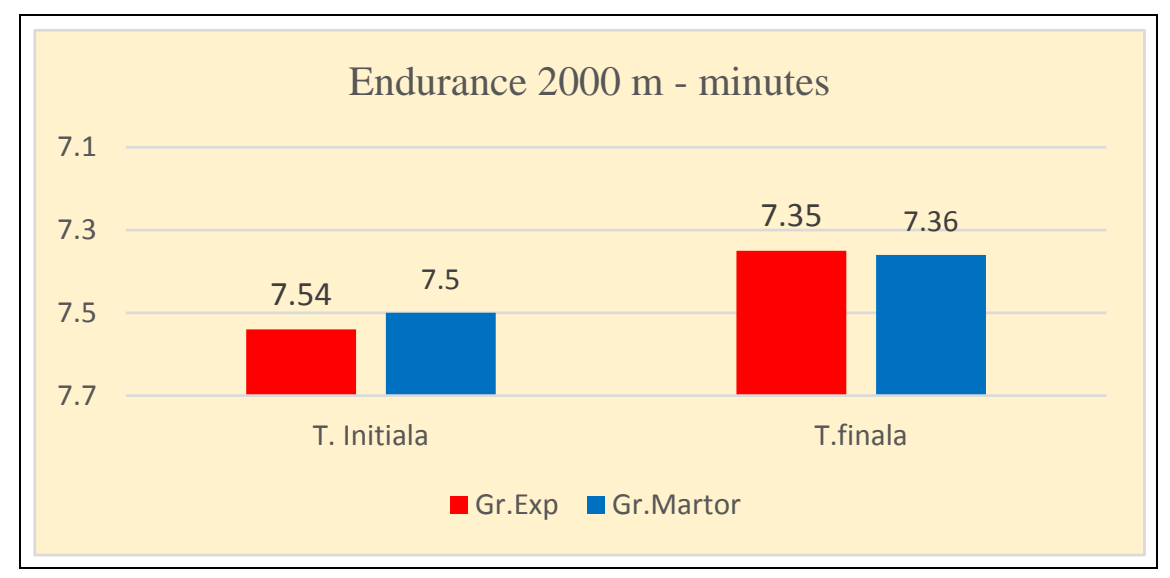

Figure 1. Results for the test „, Endurance 2000 meters”

For the „Endurance 2000 meters” test, the final arithmetic mean of the experimental group is 7.35 minutes, compared to the final mean of the control group, which is 7.36 minutes, an increase of 0.01 minutes in favour of the experimental group, thus statistically insignificant differences between the two groups $(\mathrm{t}=0,017)$.

Graphical expression regarding the arithmetic mean of the initial and final tests „Long pass”

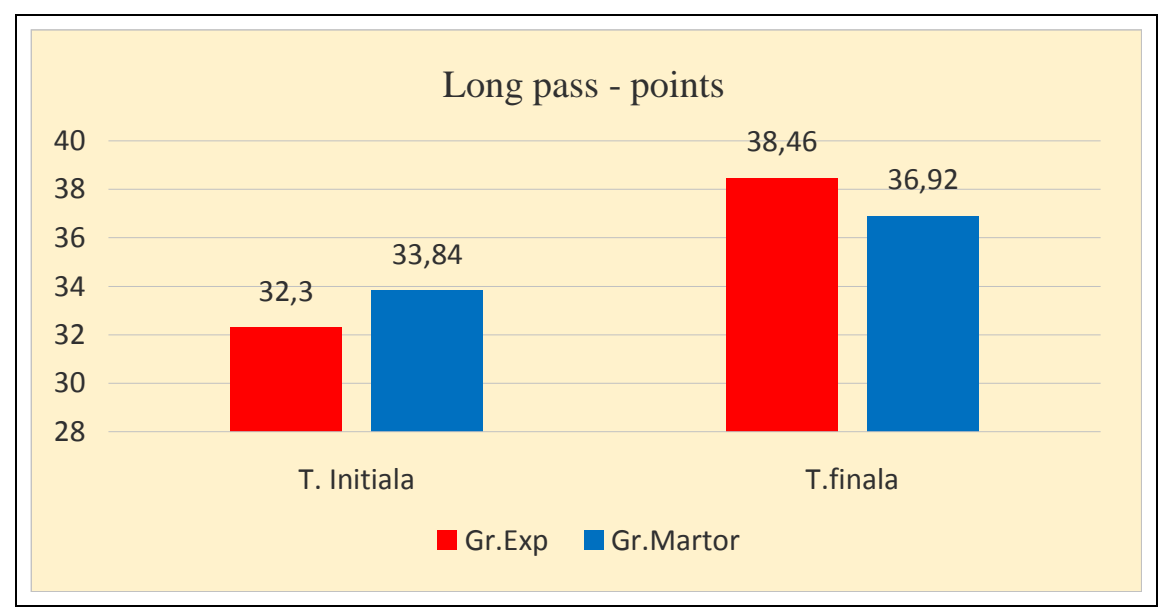

Figure 2. Results for the test „Long pass”

For the „Long pass” test, the final arithmetic mean of the experimental group is 38,46 points, compared to the final mean of the control group, which is 
36,92 points, an increase of 1,54 points in favour of the experimental group, thus statistically insignificant differences between the two groups $(t=1,5)$.

Graphical expression regarding the arithmetic mean of the initial and final tests ,,Toulouse-Pieron”

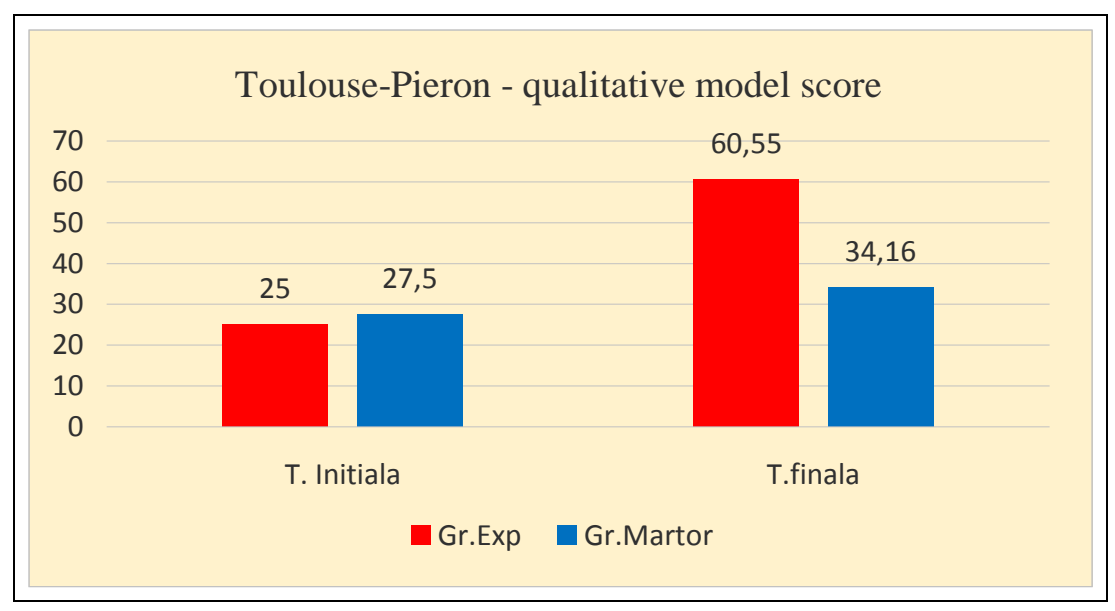

Figure 3. Results for the test „Toulouse-Pieron”

For the „Toulouse-Pieron”, test, the final arithmetic mean of the experimental group is 60,55 points, compared to the final mean of the control group, which is 34,16 points, an increase of 26,39 points in favour of the experimental group, thus statistically significant differences between the two groups $(\mathrm{t}=10,86)$.

\section{Discussions}

The existence of significant differences in favor of the experimental group compared to the control group on the Toulouse-Pieron test, in conjunction with the insignificant differences of the physical and technical testing, emphasizes a conclusive development of the level of concentrated attention, obtained as a result of carrying out the training program. These results and findings may help coaches in the development of comprehensive training curricula, which ,by the training methods and means they use, contribute not only to the improvement of the physical, technical and tactical preparation of athletes, but also to the improvement of certain psychological traits and to a much better management of the last few minutes of the match in order to obtain higher results in competitions.

\section{Conclusions}

1. The performed experiment confirmed the hypotheses of the research, emphasizing by the recorded values an improvement of the concentration ability of the experimental group, which led to an increase of the efficiency of a junior 
football player towards the end of a match and thus to a better management of the last minutes of the match.

2. Coaches can develop more complete training programs by proposing as many "games" of attention as possible; these games, based on the specific elements of training methods and means will contribute not only to the improvement of the specific preparation of the athletes, but also to the improvement of certain psychological traits and qualities.

3. It is recommended to use exercises of concentration and mobility of attention at the end of the training session, when fatigue is higher and it is recommended to be short (maximum 10 minutes), and the content mut be simple and attractive.

4. Knowledge of the individual faults and qualities of group members and the qualities and the flaws of the group as a whole in terms of technical, tactical, physical, theoretical and psychological perspective, by the coach, is the optimal solution to take the necessary decisions in critical moments of a match.

\section{References}

1. COTTRAUX, J. (2005). Les therapies comportementales et cognitives, Paris: Masson;

2. DRĂGAN, A. (2008). Optimizarea lecţiei de antrenament la disciplina fotbal, Galati: University Press;

3. DRAGAN, A., OPREA, A. (2007). Abordări interdisciplinare în fotbal, Galaţi: Academica;

4. EPURAN, M., HOLDEVICI, I., TONIŢĂ, F. (2001). Psihologia sportului de performanţă. Teorie şi practică, Bucureşti: Fest;

5. GAGEA, A. (2007). Cercetări interdisciplinare în sportul de performanţă, Bucureşti: Ministerul Internelor şi reformei Administrative;

6. HNIATIUC, A.(2008). Revista Antrenorul nr.22, Bucuresti: S.F.A.;

7. MAZZANTINI, M., BOMBARDIERI, S. (2013). Italian academy training session for U15-U18, Edited by Alex FitzgeraldSoccerTutor.com.;

8. RADULESCU, M., COJOCARU,V. (2003). Ghidul antrenorului de fotbal- copii si juniori, Bucuresti: Axis Mundi;

9. http://www.frf.ro/sites/default/files/fisiere/TESTE\%20TEHNICE\%20\%JU NIORI20\%.pdf. 


\title{
EXPERIMENT PRIVIND GESTIONAREA ULTIMELOR MINUTE ALE UNUI J OC DE FOTBAL LA J UNIORI REPUBLICANI
}

\author{
Savu Vasile Cătălin ${ }^{1}$ \\ Moisescu Petronel Cristian² \\ 1,2Universitatea “Dunărea de Jos” din Galați, Str. Gării nr. 63-65, 800003, Romania
}

Cuvinte cheie: fotbal, final de joc, concentrare, juniori

\begin{abstract}
Există o multitudine de factori care pot influenţa randamentul unui jucător junior de fotbal pe finalul unui joc; o greşeala tehnică, o condiţie fizică insuficient pusă la punct sau o lipsă de concentrare, fapt care duce în cele mai multe cazuri la pierderea meciului sau a unor puncte. Antrenori de la diverse echipe de juniori si chiar de seniori, pentru a motiva rezultatul negativ, explică eşecurile sau lipsa de randament a unui jucător sau a echipelor pe care le conduc prin expresia ,în momentele decisive din finalul partidei jucătorii mei au dat dovadă de lipsă de concentrare”. În acest sens, pentru a depista care factor este determinant, trebuie făcută o analiză riguroasă privind gestionarea ultimelor minute ale unei partide de fotbal astfel încât să putem identifica si combate pe viitor efectele negative ale acestuia.
\end{abstract}

\section{Introducere}

Referitor la profesia de antrenor rolul acestora constă nu numai în pregătirea sportivilor ci şi să-i facă pe jucători să se capaciteze la maxim în timpul meciurilor dar mai ales în cazul finalurilor de joc când intervin factorii interni si externi (miza jocului, presiunea publicului, oboseala, prestaţie nesatisfăcătoare a arbitrilor, precipitare, emoții, etc. (Mazzantini \& Bombardieri, 2013). Pentru a reuşi acest lucru, antrenorul trebuie să cunoască în amănunt punctele forte si slabe ale fiecărui jucător în parte dar şi în ansamblu al echipei, în urma unor teste şi analize obiective, pentru a lua deciziile ce se impun în momentele importante ale jocului.

Aceste teste şi analize se referă la toţi factorii antrenamentului sportiv deşi unii specialişti (Epuran, Holdevici, \& Toniţă, 2001; Hniatiuc, 2008) consideră că finalurile de joc ţin de psihicul jucătorilor, de capacitatea de mobilizare şi concentrare a atenţiei. Deci atenţia este necesară oricărui tip de activitate, ea intervine în orice activitate conştientă, însoţind toate procesele psihice (Cottraux, 2005).

Referitor la jocul de fotbal, solicitările maxime şi de durată din timpul jocului slăbesc treptat capacitatea atenţiei (Rădulescu \& Cojocaru, 2003). Din aceasta cauză daca vrem sa aflam cauza eşecurilor unui jucător trebuie mai întâi sa evaluam capacitatea acestuia pe fiecare factor al antrenamentului sportiv (Dragan \& Oprea, 2007). 
În concluzie pentru un management bun al sfârşiturilor de joc antrenorul trebuie să cunoască foarte bine profilul psihologic al fiecărui jucător in parte (calităţi+defecte) dar şi a grupului (relații, divergente intre jucători, probleme etnice, de religie, etc.) pentru a lua deciziile cele mai bune in timpul jocului dar mai ales in momentele critice si tensionate din finalurile de joc.

Scopul acestei lucrări este de a identifica şi de a combate acei factori care pot influenţa randamentul unui jucător junior de fotbal pe finalul unui joc, prin implementarea unor mijloace specifice de pregătire, în vederea obţinerii unor rezultate superioare în competiţie.

Ipotezele cercetării:

1. Se consideră că identificarea şi combaterea acelor factori care pot influenţa randamentul unui jucător junior de fotbal pe finalul unui joc pot conduce la obţinerea unor rezultate superioare în competiţie.

2. În ce măsură metodele şi mijloacele utilizate pe finalul antrenamentului vor influenţa capacitatea de gestionare a ultimelor minute ale unui joc de fotbal la nivelul juniorilor republicani.

\section{Material şi metode}

Grupele cuprinse in cercetare sunt: A.S.C.M. Dunărea Galaţi - grupa experiment şi L.P.S. Galaţi - grupa de control formate din juniori under 19 fiecare având in componenţă 18 jucători.

Experimentul s-a desfăşurat pe terenul „Dunarea 2" si ,Siderurgistul” din Galaţi, unde suprafaţa de joc este din gazon artificial, astfel încât pregătirea echipelor nu a fost influenţată de conditiile meteo. Prezentul experiment s-a desfăşurat pe parcursul unui retur competiţional (01.03.2016 - 31.05. 2016).

Teste de evaluare - Pentru analiza factorilor antrenamentului sportiv ce pot influenţa gestionarea ultimelor minute ale unui joc de fotbal au fost aplicate un număr de trei teste.

Descrierea testelor aplicate:

1. Pentru măsurarea factorului fizic s-a aplicat testul - Anduranţă $2000 \mathrm{~m}$

Execuţie: La comanda „,pe locuri”, jucătorii se plasează aproape de linia de plecare, fără a o atinge. La fluier (sau la alt semnal acustic) ei parcurg distanşa de $2000 \mathrm{~m}$ în cel mai bun timp. Cronometrul se opreşte în momentul în care pieptul alergătorului trece linia de sosire.

2. Pentru măsurarea factorului tehnic s-a aplicat testul - Pasa lungă

Marcaj: Marcajul careului de $5 \mathrm{~m}$ să fie vizibil.

Execuţie: Jucătorul trebuie să execute 3 pase lungi în careul de $5 \mathrm{~m}$ latură.

Reguli:

- mingea este statică. mingea care cade pe linia careului = reuşită.

- pasă lungă reuşită $=20$ pct.

Rezultat: Suma punctelor.

3. Pentru măsurarea factorului psihologic s-a aplicat testul de atenţie concentrată - Toulouse-Pieron 
Construcţie:

- 4 pătrate cu bară (codiţă) date ca mode

- 23 de şiruri a câte 20 de pătrate cu bară plasată fie în colţuri, fie pe laturile pătratului

- Sarcina subiectului:

- este de a găsi şi de a bara cele 4 pătrate date ca model, lucrând simultan

- greşeala pe care subiectul şi-o sesizează, o poate remedia încercuind pătratul

Durata: 6 minute

Analiza rezultatelor:

Acest test permite diagnosticarea atenţiei atât sub aspect cantitativ, cat si sub aspect calitativ. În marginea din dreapta a foii se vor trece 3 coloane:

- c-reprezentând semnele corect barate

- g-reprezentând semnele greşit barate

- o-reprezentând semnele omise.

Pentru aprecierea calitatii,se aplica formula: Calitate $=\mathrm{Tc}-\mathrm{Tg} / \mathrm{Tc}+\mathrm{To}$

În urma analizei rezultatelor înregistrate la testările iniţiale, pentru grupa experiment a fost elaborat şi aplicat un program experimental de pregătire cu mijloace specifice care să vizeze dezvoltarea factorilor antrenamentului sportiv în vederea gestionarii la un nivel superior a ultimelor minute dintr+un joc. Programul experimental de pregătire a fost structurat pe parcursul a 3 luni, cu trei antrenamente pe săptămână ( luni, miercuri si vineri) câte 10 minute, inainte de revenirea după efort a jucătorilor.

Grupa martor a lucrat după programul propriu de pregătire acesta constând pe finalul antrenamentului in joc la două porţi pe jumătate de teren. Dintre modelele de exerciţii utilizate în vederea imbunătăţirii factorilor antrenamentului sportiv exemplificăm:

1. Jocuri $4 x 4$ - Într-un careu de 30x20m avem 4 echipe de cate 2 jucatori cu maieuri diferite. Se joacă 2 echipe a cate doua culori (ex. rosu+verde galben+albastru). Fiecare culoare are poarta sa de aceeasi culoare cu echipamentul formata din jaloane cu o distanta de doi metri. Atunci când o echipa are mingea trebuie sa marcheze in portile colorate ale celeilalte echipe. Echipele se schimba la fluierul antrenorului dupa un anumit timp si incerca sa inscrie in noile porti. Timp de lucru 2 reprize x 4'; pauză 1 `.

2. Jocuri $5 \times 5$ - Într-un careu de $30 \times 20 \mathrm{~m}$, două porţi de $5 / 2 \mathrm{~m}$ cu portari. Avem 4 echipe a cate doi jucatori cu maieuri distincte (rosu, portocaliu, verde, albastru).Se joacă 4 contra 4 dar fiecare echipa este alcatuita din 2 grupuri de jucatori $\mathrm{cu}$ aceleasi maieuri (ex. rosu+albastru versus portocaliu+verde). Antrenorul anunta echipele de inceput iar in timpul jocului schimba echipele in functie de culori iar fiecare echipa va ataca la poarta indicata.Timp de lucru 3 reprize x $33^{\prime}$; pauză $1^{`}$.

3. Jocuri $5 \times 5$ - Într-un careu de $45 \times 30 \mathrm{~m}$, la 2 porţi normale cu 2 portari. Se joacă în zona de la mijlocul careului, pe perechi de jucatori, cu marcaj strict, fiecare pereche având un număr. După un anumit număr de pase, antrenorul 
striga un numar, iar jucatorul aflat in posesia mingei trebuie sa-i paseze coechipierului de la numarul strigat care poate intra în zona de finalizare în situaţie de $1 \mathrm{x} 1 \mathrm{cu}$ portarul. Jucatorul pereche trebuie sa-l impiedice sa finalizeze. Timp de lucru 2 reprize x 5 ; pauză 1 '.

4. Jocuri $5 \times 5$ - Careu de $40 \times 40 \mathrm{~m}$. Se joacă la o poartă regulamentară, improvizată din jaloane, aşezată în mijlocul terenului, unde apără doi portari care se află unul în spatele celuilalt, sau apără un portar care trebuie să se orienteze mereu unde se află mingea. Se joacă din două şi o atingere. Se marchează de oriunde. Se poate şi cu pasă lungă peste poartă şi apare finalizarea din direcţia opusă. Timp de lucru 2 reprize x $4{ }^{`}$; pauză 1 '.

5. Jocuri $5 x 5$ - Careu 50x 20m, împărţit în trei zone, două porţi de $5 / 2 \mathrm{~m}$ cu portari. Două zone de $20 \times 20 \mathrm{~m}$ şi una de $10 \times 20 \mathrm{~m}$. În zonele de $20 \times 20 \mathrm{~m}$ se joacă $2 \times 2$, iar în zona de $10 \times 20 \mathrm{~m}$ se joaca $1 \times 1$ jucătorul avand sarcina sa puna in valoare atacantii. Acest jucător nu poate participa la finalizare. Jucătorii atacanti trebuie să înscrie prin acţiune individuală sau prin combinaţii cu coechipierul, cât mai multe goluri. Jucatorii aparatori trebuie sa-i impiedice pe jucatorii atacanti sa inscrie, iar daca recupereaza mingea sa joace cat mai repede cu jucatorul mijlocas. Timp de lucru 2 reprize x 5`; pauză 1 `.

\section{Rezultate şi discuţii}

În urma aplicării programei experimentale de pregatire s-au înregistrat următoarele rezultate:

Tabel 1 Rezultate obţinute după testări

\begin{tabular}{|c|c|c|c|c|c|c|c|c|c|c|c|c|}
\hline \multirow{3}{*}{$\begin{array}{c}\text { Test } \\
\text { Grupa } \\
\text { Test } \\
\end{array}$} & \multicolumn{4}{|c|}{$\begin{array}{c}\text { Anduranță } 2000 \mathrm{~m} \\
\text { (minute) }\end{array}$} & \multicolumn{4}{|c|}{$\begin{array}{l}\text { Pasa lungă } \\
\text { (puncte) }\end{array}$} & \multicolumn{4}{|c|}{$\begin{array}{c}\text { Toulouse-Pieron } \\
\text { (punctaj etalon calitativ) }\end{array}$} \\
\hline & \multicolumn{2}{|c|}{ Experiment } & \multicolumn{2}{|c|}{ Control } & \multicolumn{2}{|c|}{ Experiment } & \multicolumn{2}{|c|}{ Control } & \multicolumn{2}{|c|}{ Experiment } & \multicolumn{2}{|c|}{ Control } \\
\hline & Initial & Final & Initial & Final & Initial & Final & Initial & Final & Initial & Final & Initial & Final \\
\hline \begin{tabular}{|c|}
$\begin{array}{c}\text { Media } \\
\text { aritmetica }\end{array}$ \\
\end{tabular} & 7.54 & 7.35 & 7.50 & 7.36 & 32.30 & 38.46 & 33.84 & 36.92 & 25 & 60.55 & 27.5 & 34.16 \\
\hline $\begin{array}{l}\text { Abaterea } \\
\text { standard }\end{array}$ & 0.171 & 0.049 & 0.185 & 0.065 & 10.12 & 9.87 & 9.60 & 11.09 & 4.20 & 6.39 & 6.47 & 8.08 \\
\hline $\begin{array}{c}\text { Coef. de } \\
\text { variab. \% }\end{array}$ & 2.278 & 0.66 & 2.471 & 0.88 & 31.34 & 25.66 & 28.38 & 30.04 & 16.80 & 10.55 & 23.54 & 23.67 \\
\hline $\begin{array}{l}\text { Eroarea } \\
\text { medie m }\end{array}$ & 0.04 & 0.0115 & 0.043 & 0.015 & 2.38 & 2.32 & 2.26 & 2.61 & 0.99 & 1.50 & 1.52 & 1.907 \\
\hline $\mathbf{m}^{2}$ & 0.0016 & 0.00013 & 0.0019 & 0.0002 & 5.7 & 5.41 & 5.13 & 6.84 & 0.98 & 2.27 & 2.33 & 3.64 \\
\hline $\begin{array}{c}\text { Test semnif. } \\
\mathrm{t}=1.95 \\
\end{array}$ & & 0.017 & & & & & & & & & 10.86 & \\
\hline
\end{tabular}

Exprimarea grafică privind media aritmetică a testările iniţiale şi finale la proba „Anduranta 2000 metri”

La proba „Anduranta 2000 metri”, media artimetică finală a grupei experimentale este de 7,35 minute, faţă de media finală a grupei martor care este de 7,36 minute, creşterea fiind de 0,01 minute, în favoarea grupei experimentale, aceasta insemnand diferenţe nesemnificative statistic intre cele doua grupe $(\mathrm{t}=0,017)$. 


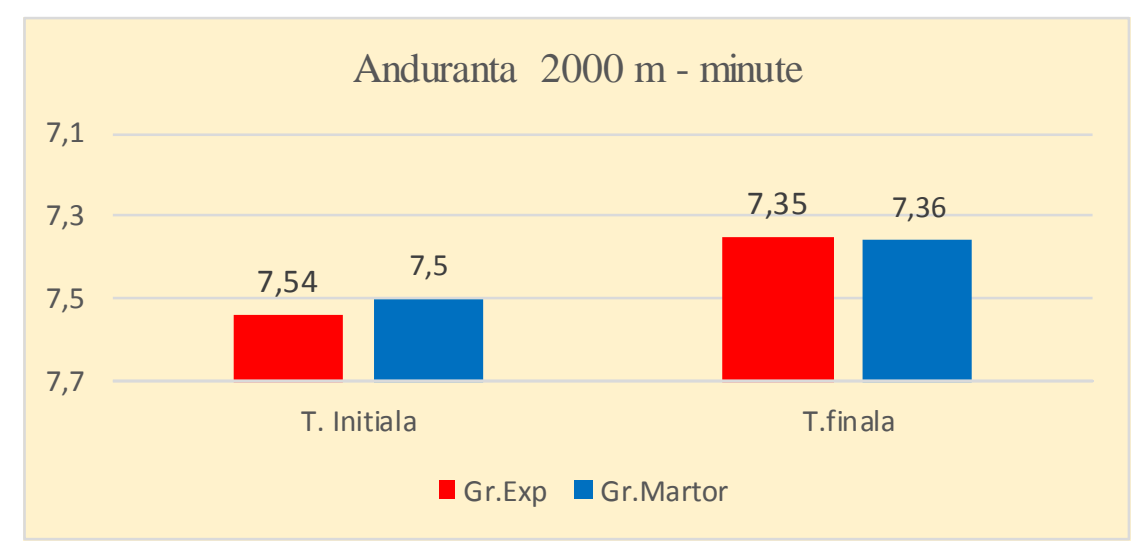

Figura 1. Rezultatele probei "Anduranta 2000 metri”

Exprimarea grafică privind media aritmetică a testările iniţiale şi finale la proba „,Pasa lunga”

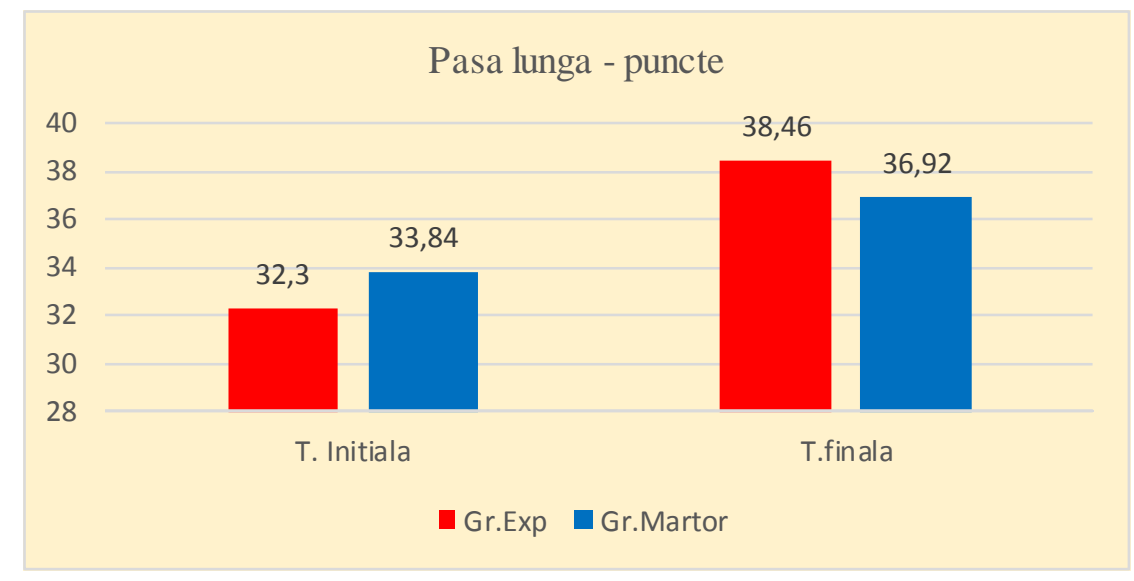

Figura 2. Rezultatele probei „Pasa lunga”

La proba „Pasa lunga”, media artimetică finală a grupei experimentale este de 38,46 puncte, faţă de media finală a grupei martor care este de 36,92 puncte, creşterea fiind de 1,54 puncte, în favoarea grupei experimentale, aceasta insemnand diferenţe nesemnificative statistic intre cele doua grupe $(t=1,5)$.

Exprimarea grafică privind media aritmetică a testările iniţiale şi finale la proba ,,Toulouse-Pieron” 
La proba „Toulouse-Pieron”, media aritmetică finală a grupei experimentale este de 60,55 puncte, faţă de media finală a grupei martor care este de 34,16 puncte, creşterea fiind de 26,39 puncte, în favoarea grupei experimentale, aceasta însemnând diferenţe semnificative statistic intre cele doua grupe $(\mathrm{t}=10,86)$.

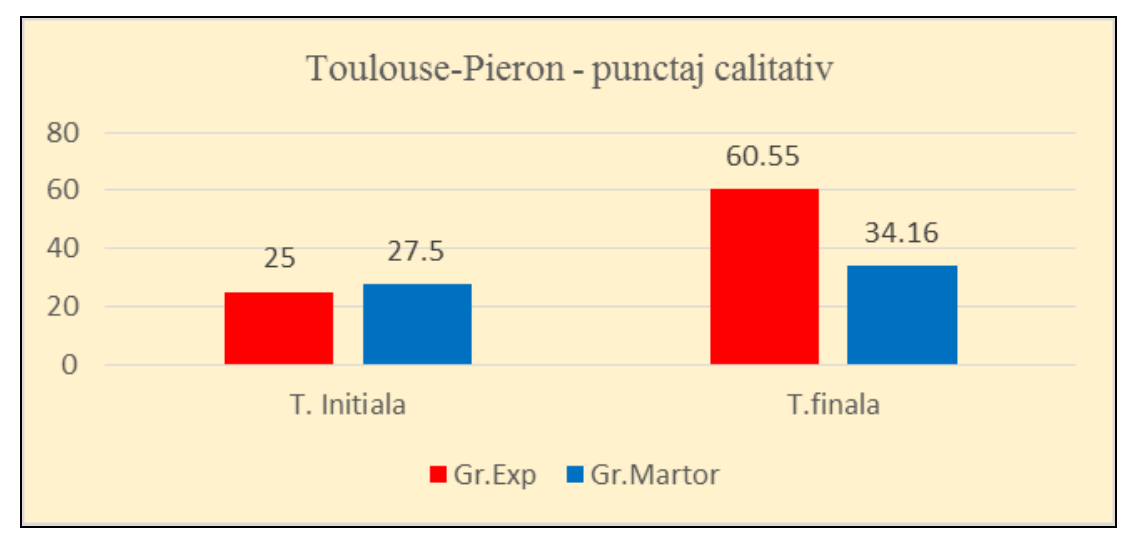

Figura 3. Rezultatele probei „Toulouse-Pieron”

\section{Discuţii}

Existenţa unor diferenţe semnificative in favoarea grupului experimental faţă de grupul martor la testul Toulouse-Pieron, coroborată cu diferenţe insignifiante la testarea fizică si tehnică, evidenţiază o dezvoltare concludentă a nivelului atenţiei concentrate, obţinută ca rezultat al aplicării programului de pregătire. Aceste rezultate si constatări îi pot ajuta pe antrenori în elaborarea unor programe mai complete de instruire, care prin specificul metodelor şi mijloacelor de antrenament, să contribuie nu numai la îmbunătăţirea pregătirii fizice şi tehnico-tactice a sportivilor, ci şi la perfecţionarea unor trăsături şi însuşiri psihice în vederea gestionării mult mai bine a ultimele minute ale jocului în vederea obţinerii unor rezultate superioare în competiţie.

\section{Concluzii}

1. Experimentul întreprins confirmă ipotezele cercetarii, evidenţiind prin valorile înregistrate îmbunătăţirea capacităţii de concentrare la lotul experimental, lucru care duce la creşterea randamentului unui jucător junior de fotbal pe finalul unui joc si implicit la gestionarea mai bună a ultimelor minute din meci. 
2. Antrenorii pot elabora programe mai complete de instruire, prin efectuarea a cât mai multe "jocuri" de atenţie cu tematică, care prin specificul metodelor şi mijloacelor de antrenament să contribuie nu numai la îmbunătăţirea pregătirii specifice a sportivilor, ci şi la perfecţionarea unor trăsături şi însuşiri psihice.

3. Sunt recomandate folosirea unor exerciţii de concentrare şi de mobilitate a atenţiei, la sfârşitul antrenamentului când oboseala este mai crescută şi se recomandă ca acestea să aibă o durată scurtă (maxim10 min), iar conţinutul să fie cât mai simplu şi atractiv.

4. Cunoasterea calităţilor si defectelor individuale ale membrilor grupului cât şi calităţile si defectele grupului în ansamblu din punct de vedere fizic, tactic, tehnic, teoretic, psihologic de către antrenor este soluţia optimă pentru a lua deciziile ce se impun in momentele critice ale unui joc. 